\title{
SIGHT-GLASS DEGRADATION IN UREA CARBAMATE SOLUTION
}

\author{
Dikdik YUliana, Hengki IraWAN* \\ Departement of Reliability, PT. Pupuk Sriwidjaja Palembang. Indonesia \\ *Corresponding author: hengki.irawan@pusri.co.id
}

(Received: 1 November 2021; Accepted: 12 December 2021; Published on-line: 1 March 2021)

\begin{abstract}
In the industrial environment, a sight glass acts as a gauge for the fluid level in a pressure vessel. Sight glass must have the following physical properties: clarity (clear enough to view the fluid in the vessel), hardness (not easily broken), thermal shock resistance, and corrosion resistance. A historical investigation of the equipment placed in the HighPressure Decomposer (HPD) unit of the Urea Plant-X and Plant-Y has a pressure of 17 Bar and a temperature of $124-155^{\circ} \mathrm{C}$, yielded an analysis of sight glass degradation in carbamate solution. The sight glass that was installed is soda-lime fused glass. The average is based on the equipment's history.
\end{abstract}

KEY WORDS: soda-lime fused glass, sight glass corrosion, carbamate solution

\section{INTRODUCTION}

Failure is almost an unavoidable phenomenon for all industrial systems, which can be repaired due to the possibility of damage and human error $[1,2]$. In the fertilizer industry, One of the vital equipment in the fertilizer industry is a High-Pressure Decomposer (HPD). Sight glass at HPD is an important component. Sight Glass is a transparent material that allows operators to determine the level of fluid in a vessel. Sight glass is a form of glass material composed of non-crystalline silicate mixed with other oxides such as $\mathrm{CaO}, \mathrm{Na}_{2} \mathrm{O}, \mathrm{K}_{2} \mathrm{O}$, and $\mathrm{Al}_{2} \mathrm{O}_{3}$ as a mixed material that impacts the material's properties [3, 4]. Table 1 shows some of the most prevalent commercially manufactured glass materials, as well as others. The higher the amount of fused silica in a material, the higher the glass transition temperature (resistance to high temperatures). The denser the glass structure, the more resistant it is to thermal expansion. Adding $\mathrm{Al}_{2} \mathrm{O}_{3}$ to the glass structure can increase the crystalline structure in the amorphous glass structure, increasing toughness. However, it can also reduce corrosion resistance, necessitating the addition of additional Sodium Oxide $\left(\mathrm{Na}_{2} \mathrm{O}\right)$ and calcium oxide $(\mathrm{CaO})$ as network modifications to minimize the potential for structural degradation due to chemical contact. Boron Oxide $(\mathrm{BaO})$ added to the sight glass structure can reduce thermal expansion and boost corrosion resistance in low $\mathrm{pH}$ two solutions $[3,5,6]$.

Urea carbamate solution results from the reaction between $\mathrm{CO}_{2}$ gas, $\mathrm{NH} 3$, and recycled carbamate in a urea reactor with a reaction pressure of 200 bar and a temperature of $190^{\circ} \mathrm{C}$. The pressure of the solution was lowered from 200 bar to $17-19$ bar at $124-155^{\circ} \mathrm{C}$ in a HighPressure Decomposer (HPD). This vessel separates the unreacted gas from the carbamate solution that has been generated. The HPD constituent material is coated with a corrosionresistant coating in the form of a lining utilizing NTK R-4 $(25.5 \mathrm{Cr}-3,5 \mathrm{Ni}-1,5 \mathrm{Mo})$ material with a corrosion rate of $0.008 \mathrm{~mm} / \mathrm{year}$ three because the carbamate solution is very corrosive. Several sight glasses are fitted in the HPD Vessel to allow the Operator to monitor the amount of carbamate solution in the HPD. These sight glasses must endure thermal stress loads and be 
resistant to carbamate solutions. The objective of this work is to investigate sight glass of sodalime fused glass degradation in a urea carbamate environment

\section{MATERIALS AND METHODS}

High-Pressure Decomposer (HPD) equipment was being used in the fertilizer industry [7]. In this work, the glass used as a sight glass in the High-Pressure Decomposer (HPD) is a form of soda-lime glass that has been fully tempered and has a low melting point. It is commonly used for food containers. Table 1 . shows the physical parameters of soda-lime glass in detail. Table 2 and Table 3 show the results of mechanical and physical testing methods used to determine the composition of the sight glass, including the gravimetric method, Atomic Absorption Spectrophotometer (AAS), and Energy Dispersive X-Ray (EDAX).

Table 1: Physical Properties of soda-lime glass

\begin{tabular}{cc}
\hline \multicolumn{2}{c}{ Physical Properties } \\
\hline Coefficient thermal expansion & $8.8-9.0 \mu \mathrm{m} / \mathrm{m}-\mathrm{K}$ \\
Knoop hardness & 570 \\
Tensile Strength & $2100 \mathrm{Psi}$ \\
\hline
\end{tabular}

Table 2: Destructive test results sight glass test with gravimetric and AAS methods.

\begin{tabular}{cccccc}
\hline $\begin{array}{c}\text { Sight } \\
\text { Glass }\end{array}$ & $\begin{array}{c}\mathrm{SiO}_{2} \\
(\boldsymbol{\%})\end{array}$ & $\begin{array}{c}\mathrm{Na}_{2} \mathrm{O} \\
(\boldsymbol{\%})\end{array}$ & $\begin{array}{c}\mathrm{Al}_{2} \mathrm{O}_{3} \\
(\boldsymbol{\%})\end{array}$ & $\begin{array}{c}\text { Boron } \\
(\boldsymbol{\%})\end{array}$ & remark \\
Sample & Gravimetric & AAS & AAS & AAS & \\
\hline A & 57.74 & 13.15 & 0.11 & - & Soda-lime glass \\
B & 56.44 & 14.61 & 0.11 & - & Soda-lime glass \\
C & 56.51 & 12.03 & 0.09 & - & Soda-lime glass \\
D & 53.42 & 12.42 & 0.09 & - & Soda-lime glass \\
E & 56.87 & 11.95 & 0.09 & - & Soda-lime glass \\
\hline
\end{tabular}

Table 3: the results of the destructive test sight glass test with the EDX method.

\begin{tabular}{ccccccccl}
\hline $\begin{array}{l}\text { Sight } \\
\text { Glass } \\
\text { Sample }\end{array}$ & $\mathbf{0}$ & $\mathbf{N a}$ & $\mathbf{M g}$ & $\mathbf{A l}$ & $\mathbf{S i}$ & $\mathbf{K}$ & $\mathbf{C a}$ & Remarks \\
\cline { 2 - 7 } & & & & & & & & \\
\hline $\mathbf{A}$ & 40.01 & 9.40 & 2.76 & 2.42 & 36.14 & 1.04 & 8.24 & Soda-lime \\
$\mathbf{B}$ & 40.92 & 10.11 & 2.72 & 1.12 & 36.19 & 1.02 & 7.93 & Soda-lime \\
$\mathbf{C}$ & 41.96 & 9.62 & 2.93 & 1.11 & 36.75 & 0.75 & 6.88 & Soda-lime \\
$\mathbf{D}$ & 42.05 & 10.89 & 2.59 & 0.90 & 35.69 & 0.66 & 7.22 & Soda-lime \\
$\mathbf{E}$ & 38.63 & 10.36 & 2.76 & 1.46 & 38.34 & 0.93 & 7.53 & Soda-lime \\
$\mathbf{F}$ & 46.22 & 4.36 & - & 1.97 & 46.18 & - & 1.27 & Fused-silica \\
\hline
\end{tabular}

Table 4: Data sample sight glass at HPD Plant-X and Plant-Y

\begin{tabular}{llcll}
\hline No & $\begin{array}{c}\text { Sight Glass } \\
\text { Position }\end{array}$ & $\begin{array}{c}\text { Installed } \\
\text { date }\end{array}$ & $\begin{array}{c}\text { Uninstall } \\
\text { date }\end{array}$ & Lifetime \\
\hline $\mathbf{1}$ & HPD P-3 & August 2015 & July 2016 & 335 days \\
$\mathbf{2}$ & HPD P-3 & August 2015 & July 2016 & 335 days \\
$\mathbf{3}$ & HPD P-4 & August 2008 & June 2017 & 3226 days \\
$\mathbf{4}$ & HPD P-4 & August 2008 & June 2017 & 3226 days \\
\hline
\end{tabular}

The data is taken from the history of the replacement of sight glass in the High-Pressure Decomposer (HPD) unit of the Urea Plant-X and Plant-Y factories which have the same 
material and operational characteristics. The data for the sight glass samples, among others, can be seen in Table 4.

\section{RESULTS AND DISCUSSION}

The results of observations refer to the specimens in Table 4. Detailed condition of sight glass in the High-Pressure Decomposer (HPD) unit can be seen in Fig. 1. In general, all sight glass has found defects in the form of erosion in each specimen.

New Sight Glass

The condition of Sight Glass on HPD Plant-X was installed during shutdown Plant-X in August 2015. Removed in July 2016. It was eroded with $\pm 0.5 \mathrm{~mm}$ and $\propto 51 \mathrm{~mm}$

The condition of the Sight Glass on the Plant-X HPD was installed during the P-3 2015 shutdown. Removed during the July 2016 shutdown, it was eroded with a $\pm 0.5 \mathrm{~mm}, Q$

$51 \mathrm{~mm}$ and leak out

The condition of the Sight Glass on the HPD Plant-Y has been eroded with a $\pm 5.48 \mathrm{~mm}$ basin, $\propto 51 \mathrm{~mm}$. it was installed during the 2008 FY P-4

The condition of the Sight Glass on the northern HPD Plant-Y, which was broken, was installed during FY P-4
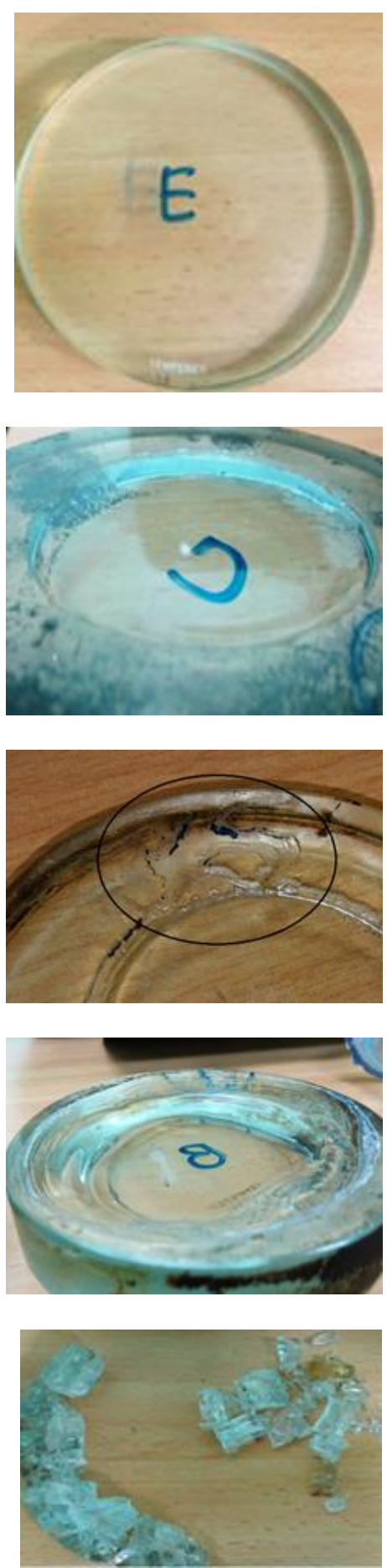

Fig. 1. HPD Sight Glass Damage Phenomenon 
Based on the data above and the results of observations and measurements of the degraded sight glass, it can be seen that corrosion has occurred in the sight glass with an average corrosion rate of $0.608 \mathrm{~mm} / \mathrm{year}$. The results of the calculation of the minimum thickness of the sight glass with fused soda-lime glass material at a maximum pressure of $17 \mathrm{bar}$ and a temperature of $125-155^{\circ} \mathrm{C}$ with the view side area (unsupported diameter) are $51 \mathrm{~mm}$ as in equation 1 .

$$
\text { Thickness Min }(\mathrm{cm})=\mathrm{U} \sqrt{\left(\frac{0.302 \times P}{A}\right)}+\mathrm{SF}
$$

where :

$U \quad$ : Unsupported Diameter $(\mathrm{cm})$

$P \quad$ : Internal Pressure $\left(\mathrm{kg} / \mathrm{cm}^{2} . \mathrm{g}\right)$

$A \quad$ : Tensile Strength sight glass $\left(\mathrm{kg} / \mathrm{cm}^{2}\right)$

$S F \quad$ : Safety Factor for sight glass high Pressure $(3 \mathrm{~mm})$

Based on Eq. 1, it is found that the minimum thickness of the soda-lime fused glass sight glass that can withstand a pressure of 17 Bar is $10.4 \mathrm{~mm}$. With the initial thickness of the sight glass being $14.49 \mathrm{~mm}$ with a corrosion rate of $0.608 \mathrm{~mm} / \mathrm{years}$, it can be seen that the Used Life of Sight Glass with the Soda-lime fused glass type is 6.73 years, it is necessary to replace the sight glass every 2 Turn Around periods (TA). From these results, a literature study was carried out from the Manufacturing Handbook of Urea Factory Design P-3 and P-4. It was found that the recommended sight glass material is Borosilicate Glass which contains Boron so that it can increase the corrosion resistance of the sight glass itself. Further evaluation and data collection are needed to determine the corrosion rate in Borosilicate Glass material.

\section{CONCLUSION}

Investigation of soda-lime fused sight glass degradation in Urea Carbamate environment has been conducted. Conclusions can be drawn from the investigation and observation of the sight glass High-Pressure Decomposer (HPD) sample:

- $\quad$ Sight glass material with soda-lime fused glass type corrodes when operated in HPD with operating pressure conditions of $17 \mathrm{Bar}$ and temperature of $125-155^{\circ} \mathrm{C}$ with a corrosion rate of $0.608 \mathrm{~mm} / \mathrm{years}$.

- For use in HPD sight glass made of soda-lime fused glass, it is necessary to replace every 6.73 years, or it is recommended every 2 Turn Around (TA) periods to prevent the unscheduled shutdown.

- $\quad$ Based on the source from the Handbook of Urea Manufacturing Factory Plant-X and Plant-Y, the standard material is Borosilicate Glass, which contains Boron, which can increase corrosion resistance, but further data analysis needs to be done.

\section{REFERENCES}

[1] H. Garg and S. P. Sharma, "Behavior analysis of synthesis unit in fertilizer plant," International Journal of Quality \& Reliability Management, vol. 29, no. 2, pp. 217-232, 2012.

[2] A. Apriansyah, H. Chandra, D. K. Pratiwi, and A. Firdaus, "Fatigue Failure on Drilling Pipe Thread: A Case Study on Drill Pipe Ss105," Indonesian Journal of Engineering and Science, vol. 1, no. 1, pp. 011-019, 2021.

[3] W. Vogel, N. Kreidl, and M. L. Barreto, Glass Chemistry. Springer Berlin Heidelberg, 2012. 
[4] S. Karlsson, "Viscosity of alumina doped soda lime silicate glasses - observation of anomaly in the linear increase as Al2O3 replaces SiO2," Journal of Non-Crystalline Solids, vol. 573, 2021.

[5] W. D. Callister and D. G. Rethwisch, Materials Science and Engineering: An Introduction, 9th Edition: Ninth Edition. John Wiley and Sons, Incorporated, 2013.

[6] Y. Er-rouissi, Z. Chabbou, N. Beloued, and S. Aqdim, "Chemical Durability and Structural Properties of A12O3-CaO-Na2O-P2O5 Glasses Studied by IR Spectroscopy, XRD and SEM," Advances in Materials Physics and Chemistry, vol. 07, no. 10, pp. 353-363, 2017.

[7] Husaini, M. Najib, and I. Hasanuddin, "Analysis of cracks in the welded zone of stainless steel pipe used in high-pressure decomposer equipment," IOP Conference Series: Materials Science and Engineering, vol. 602, no. 1, 2019. 